\title{
潮の干満部での鋼材に対する電気防食効果*
}

\section{内堀利 也**}

\section{Effects of Cathodic Protection on Steel Surface in Tidal Zone}

\author{
Toshiya Uchibori
}

In order to investigate the effects of cathodic protection on steel surface exposed in tidal zone, the following tests were conducted with mild steel plates.

Correlations between immersion time ratios (to total exposure time) and protective effects were investigated for steel plates, of which the potentials were kept within three ranges of $-900 \mathrm{mV} \sim$ $-1,000 \mathrm{mV},-1,000 \mathrm{mV} \sim 1,100 \mathrm{mV}$ and $-1,200 \mathrm{mV}$ with reference to sea-water $\mathrm{Ag} / \mathrm{AgCl}$ electrode by coupling them to galvanic anodes of $\mathrm{Zn}, \mathrm{Al}$ and $\mathrm{Mg}$.

Protective effects were calculated from the difference of weight losses between protected plates and unprotected ones.
Results obtained are as follows.

1) The protective effects are $95 \sim 98 \%$ in all the three potential ranges, if the immersion time ratios are above $95 \%$.

2) The average protective effects are $50 \sim 60 \%$ if the immersion time ratios are within the range of $40 \sim 90 \%$, but the more negative the potentials, the higher the effects.

3) The protective effects are much smaller if the immersion time ratios are below $40 \%$, but in the potentials of $-900 \mathrm{mV} \sim-1,000 \mathrm{mV}$ the effects are comparatively higher, and so it is necessary to use other corrosion control associated with cathodic protection especially in these environments.

\section{1. ま え がき}

港湾構造物には鋼矢板, 鋼管杭等の鉄鋼材が従来から さかんに使用されているが，これらの鋼材は大気，海水 および土壌の各層を縦貫しているために，その腐食の程 度と様相は多岐にわたっている。従って腐食環境に応じ た適正な防食法を併用して全体の寿命の延長を図る必要 がある。腐食環境のうち平均干潮面以下の常時電解質に 接する部分に対しては, 電気防食がほぼ完全に近い防食 効果を発揮しうるが，潮の干満によって乾湿状態を繰り 返す, いわゆる干満部 (tidal zone) に対する電気防食 のみの効果については不明の点が多い。本報告では特に 干満部の鋼材の浸漬率, 電位と防食効果の関連につき調 查した結果を述べる。

\section{2. 試 験 方 法}

\section{$2 \cdot 1$ 試片の組立}

これまで海水中の鋼材に対する、電気防食試験では Humble1) が行なったものがあるが，これでは試片の電 流密度を一定とした際の防食勃果を調査している。通常 防食効果の判定には対象物の電位を基準とするので, 本 試験では試片の電位を一定に保った際の防食効果に重点 をおいた。外部電源によって定電位とする方法は装置が 複雑となるので, 現場的に流電陽極材を十分量試片と組

* 昭和 39 年 10 月 12 日 第 11 回窝食防食討論会（仙台）にて発表

** 日本防蝕工業株式会社（東京都千代田区丸の内 1 の 1 )

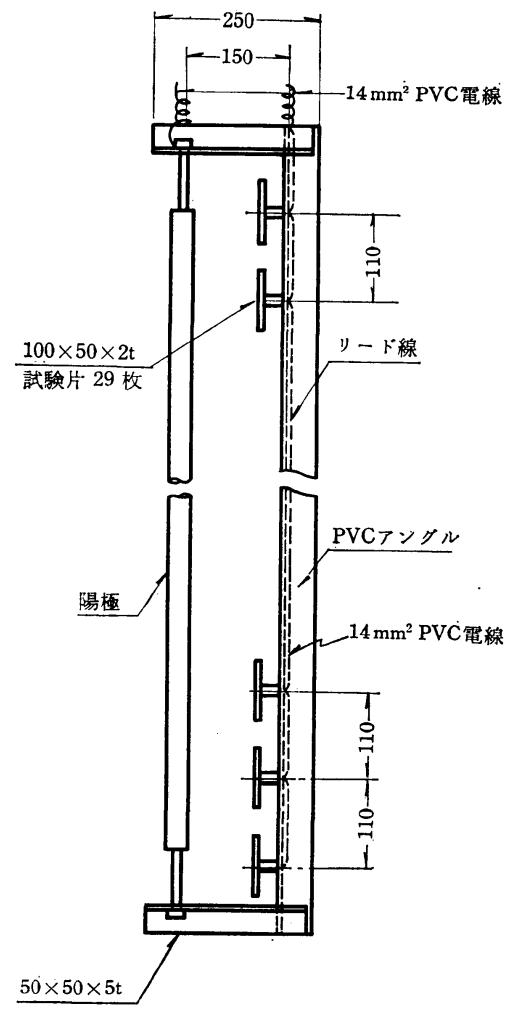

図 1 試験片組立状態 


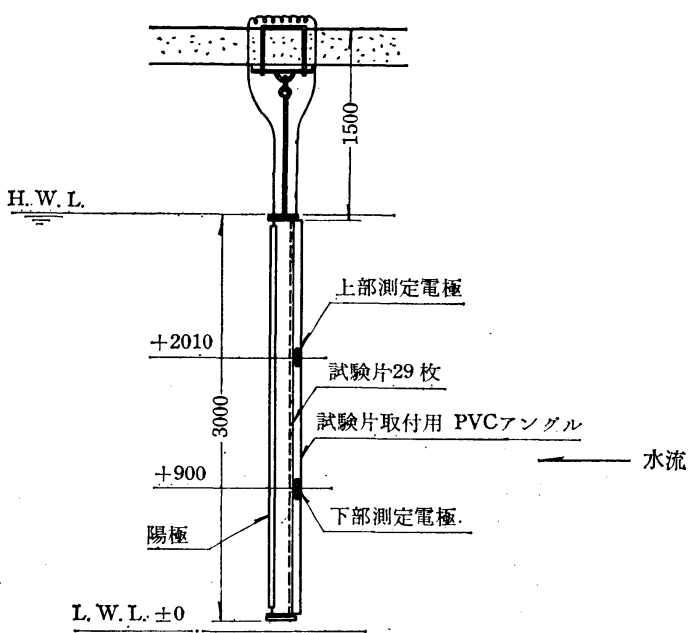

図 2 試験片吊下状態

合せて陽極材の電位に近く保持するように計画した。使 用した陽極材は $\mathrm{Mg}(\mathrm{Mg}-6 \mathrm{Al}-3 \mathrm{Zn}$ 合金, $1.315 \mathrm{in} \phi \times$ $3 \mathrm{~m}, 1$ 本) $\mathrm{Al}$ (Al-2.5 Zn-0.02 In 合金, $40 \times 40 \times 1,000$ $\mathrm{mm}, 3$ 本) および $\mathrm{Zn}(\mathrm{Zn}-0.1 \mathrm{Cd}$ 合金, $32 \times 32 \times 600$ $\mathrm{mm}, 4$ 本) である。試片は $50 \times 100 \times 2 \mathrm{t}(\mathrm{mm})$ の黒皮 付軟鋼板を使用し, 片面は土ポキシ樹脂で被覆し, これ をビニルフングルにステンレスボルトで 29 枚連続して 取り付け, 各試片は $22 \mathrm{~mm}^{2}$ ビニル電線にて相互に連結 した。 Zn の組には不通電の試片を上述のビニルアング ルの片面に 29 枚連結して取り付けた。組立後試片取付 用ボルト類にはすべてエポキシ樹脂被覆を施した。この 組立状況を図 1 に示す。 $\mathrm{Zn}, \mathrm{Al}, \mathrm{Mg}$ の組を各々以下 $\mathrm{A}, \mathrm{B}, \mathrm{C}$ 組と呼ぶ。以上のごとく組立てたものを 3 組, 図 2 のように取水路に吊り下げ 330 日間放置した。本取 水路は瀬戸内海湾に面する某製油所施設の一部で, 取水 口は護岸より数百 $\mathrm{m}$ 湾内に突出しているために, 使用 した海水は油分の混入のほとんどない清浄海水であっ た。

\section{$2 \cdot 2$ 測定}

基準電極には海水塩化銀電極を使用し，各組に 2 本当 て, 潮位 $+910 \mathrm{~mm}$ および $+2,010 \mathrm{~mm}$ の位置に取り 付け上部までリード線 $\left(0.75 \mathrm{~mm}^{2}\right.$ ビニル電線 $)$ を引き 上げ測定に便とした。通電電流 (発生電流) は同じく上 端試片からのリード線 $\left(14 \mathrm{~mm}^{2}\right.$ ビニル電線 $2 \mathrm{~m}$ 長 $)$ と 陽極からのリード線 $\left(14 \mathrm{~mm}^{2}\right.$ ビニル電線 $2 \mathrm{~m}$ 長) を 上部まで引き上げておいて連結しておき，測定時には一 たん切り離し、この間に電流計を挿入した。電位は真空 管電位差計, 電流は精密級電流計により適時測定した。

\section{$2 \cdot 3$ 試片の腐食生成物除去}

試片を水洗後, レスコール $0.5 \mathrm{wt} \%$ 添加の $5 \% \mathrm{H}_{2} \mathrm{SO}_{4}$ 液で 10 分間煮沸し, さらに $10 \% \mathrm{NaOH}$ 液で 10 分間煮
沸後水洗, ワイヤブラシで清掃した後水洗, 秤量した。 ブランクテストによると, これらの操作による地金の溶 解量は $1 \mathrm{mg} / \mathrm{cm}^{2}$ 程度であった。

\section{$3 \cdot 1$ 試片の電位変化}

\section{3. 測 定 結 果}

各試片の電位は吊下後各日数経過時において 1 回の潮 汐で試片が浸漬しはじめてから，干潮となり露出するま での間に測定するようにしたが，浸漬時間は潮汐の関係 で一定しなかった。1 回の潮汐で試片が連続して浸漬し ていた時間を横軸にとり，電位は海水塩化銀電極基準と して，各経過日数での試片の電位变化をまとめたもの 它図 3〜6 に示す。吊下後約 2 力月間は連続試片のうち

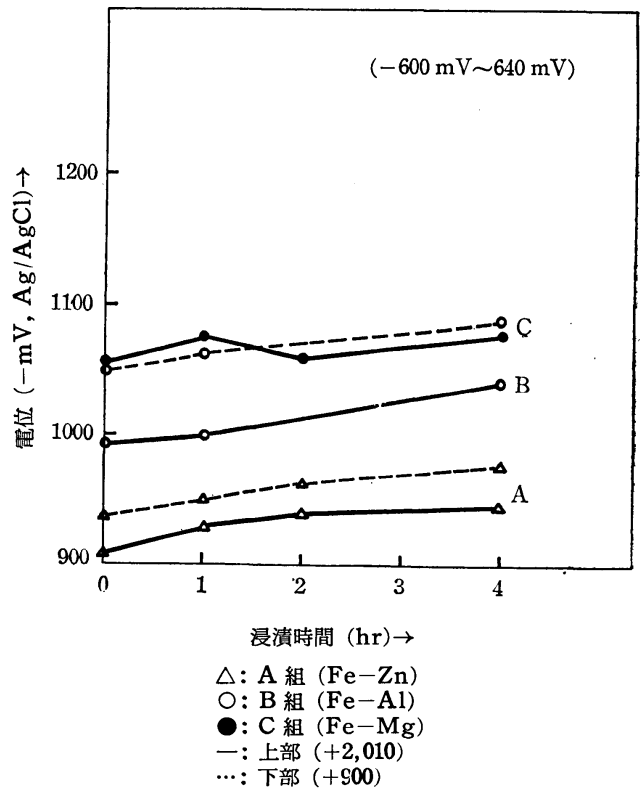

図 3 取付け 3 日後の各組電位変化状況

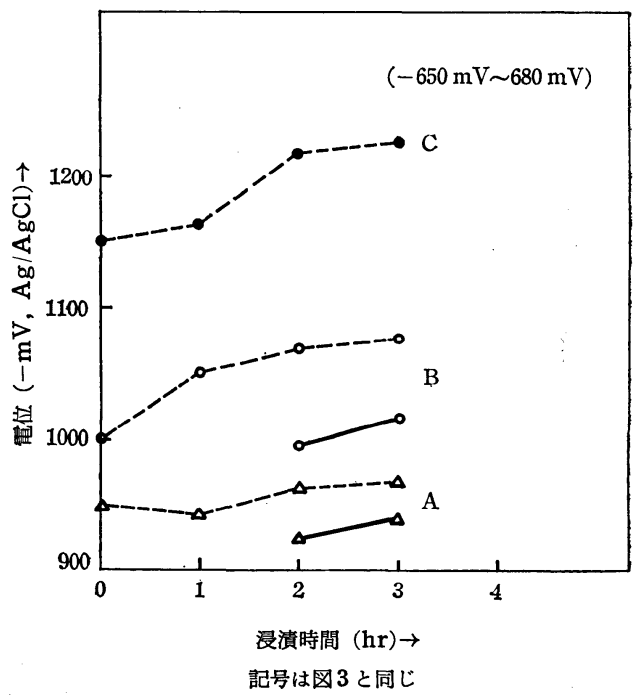

図 4 取付け 51 日後の各組電位変化状況 


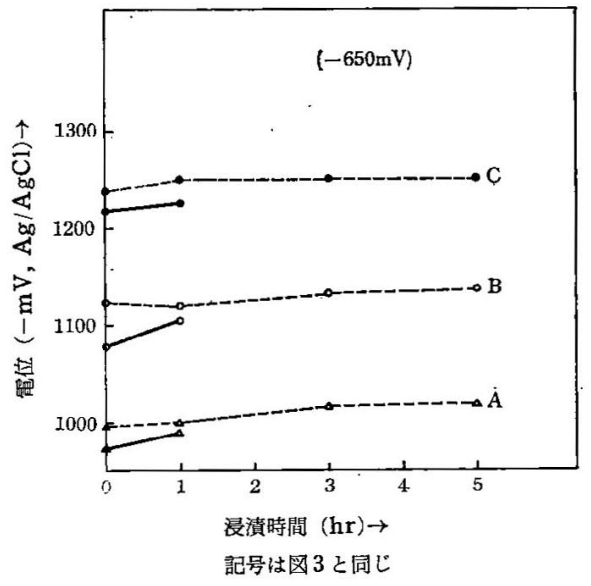

図 5 取付け 202 日後の各組電位変化状況

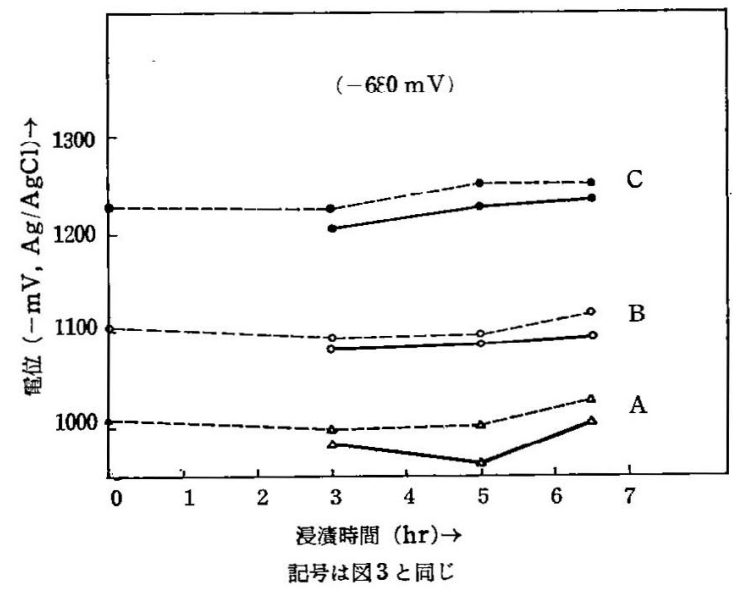

図 6 取付け 330 日後の各組電位变化状況

浸清時間の少ない上部 $(+2,010 \mathrm{~mm}$ の位置) と浸漬時間 の多い下部（+910 mm の位置）の電位，すなわち上下 位置による電位の変化に差があり,また 1 回の連続浸漬 時間内に打ける電位の変動も大きいが，2 2 月以後は上 下の位置による電位の差も少なくなり，連続浸漬時間内 に打電位の変動も少なくなっている。この結果から みると試片は大体において A 組 $-900 \mathrm{mV} \sim 1,000 \mathrm{mV}$, B組 $-1,000 \mathrm{mV} \sim-1,100 \mathrm{mV}, \mathrm{C}$ 組 $-1,100 \mathrm{mV} \sim$ $-1,200 \mathrm{mV}$ の範囲に維持されたと認められる。なお各 図の上部（）内に不通電試片の電位を記した。これでみ ると自然電位初期 $-640 \mathrm{mV}$, 後期 $-680 \mathrm{mV}$ 近辺 を示した。

\section{2 試片の表面状況}

石灰質皮膜の付着状況は $\mathrm{A}, \mathrm{B}, \mathrm{C}$ 組の順に厚く, 粗く なっている。また各組についてみると下部 $( \pm 0)$ から $1.5 \mathrm{~m}$ 近くの部分がもっとも付着量が多く，その上部 $1 \mathrm{~m}$ 近くは付着量も少なく密着むわるくなり，錆層と石 灰質波膜が入りまじり鱗片状を呈した。さらにそれ以上
の部分では錆層が多くなり石灰質皮膜の点在がみられ た。應食生成物除去後の試片の表面状態は写真 1 3 K 示すごとく石灰質皮膜付着状態と関連し，三つに区分さ れる。すなわち下部の皮膜付着の多い部分は表面状態む よく，汪とえど腐食も珰められないが，中間部分に移行 するにつれ，細かい孔食状態を呈している。この部分の みを 3 組について比較すると， A, B , C の順にこの傾向 が強くなるのが認められた。

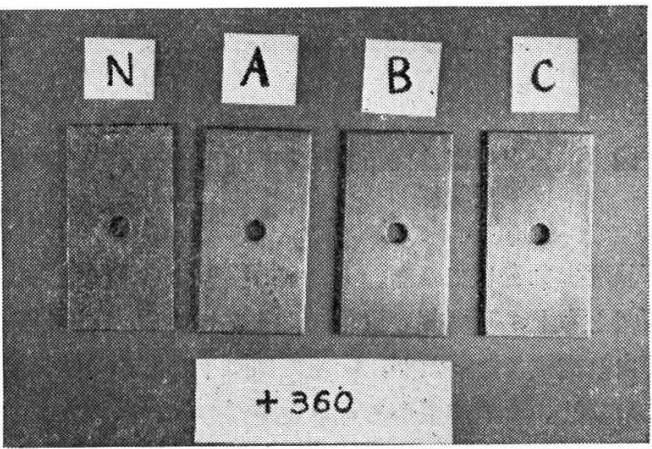

写真 1 各潮位での笍食生成物除去後の試片の表面 状態

(N：不通電陚片)

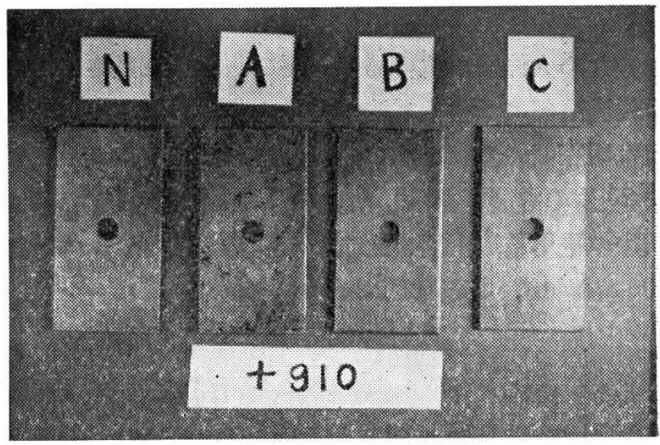

写真 2 各潮位での腐食生成物除去後の訊片の表面 状態

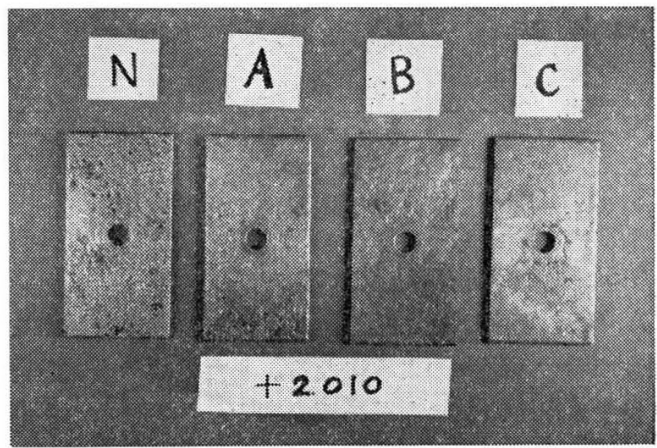

写真 3 各潮位での腐食生成物除去後の試片の表面 状態

\section{$3 \cdot 3$ 試片の皮膜特性}

試片引上げ直前リード線をはずし，不通電後の電位降 


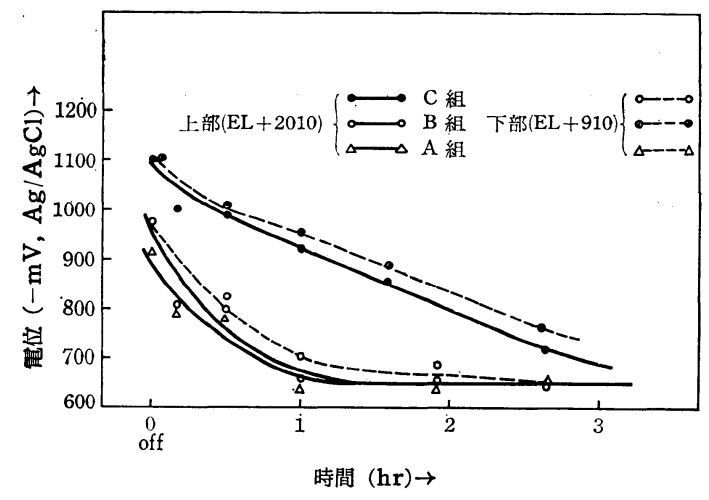

図 7 引上げ直前回路を切り離してからの試片の電 位減衰状態

下状況を測定してみた。その結果を図 7 に示す。A，B 両組とも上, 下両部の位置による差がなく, 1 時間前後 で自然電位となったが， C 組では降下時間が 3 時間程度 にのびる。この結果から見ると通常のエレクトロコーテ イングによる皮膜に比べ性能はきわめて悪い。

\section{4 通電電流の経時変化}

各組の通電電流の時間的変化をまとめものを园 8 に 示す。この電流は試片の浸漬部分に影響されるので, 比 較のため大体同潮位の場合を選び, 浸漬部長さで除して 単位浸漬部に対する電流值を求めて比較した。A，B両 組は同程度の減衰を示し, C 組は定常状態で $A, B$ 組の 約 20 倍の電流值を示した。約 7 カ月目の定常状態での 試片の平均電流密度を比較してみると, A, B 両組は約 $100 \mathrm{~mA} / \mathrm{m}^{2}, \mathrm{C}$ 組は約 $2 \mathrm{~A} / \mathrm{m}^{2}$ となる。

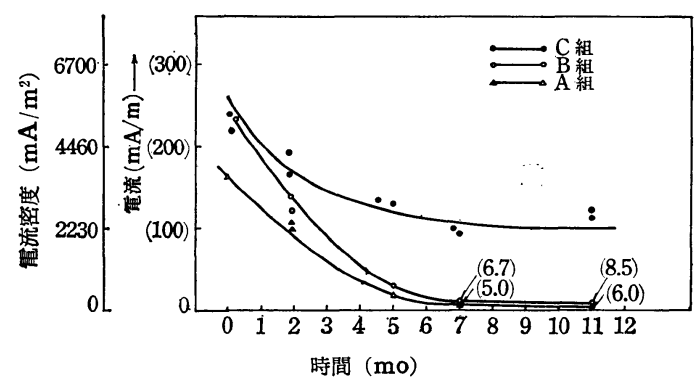

図 8 試片の通電電流の時間変化

\section{5 試片の浸淩率と防食率}

A， B，C 組および不通電試片について求めた減量を各 潮位で示すと図 9 のようになる。また試片の全試験時間 に対する浸漬時間の合計の百分率すなわち平均の浸漬率 々, 不通電試片の減量と防食試片の減量とから算出した 防食率との関係で示すと図 10 のようになる。ここで上 部約 10 枚は試片裏面のエポキシ樹脂塗膜の涂離により, 一定面積を維持できなかったので同図から除いた。不通 電試片の減量は報告されている一般の腐食傾向と類似し

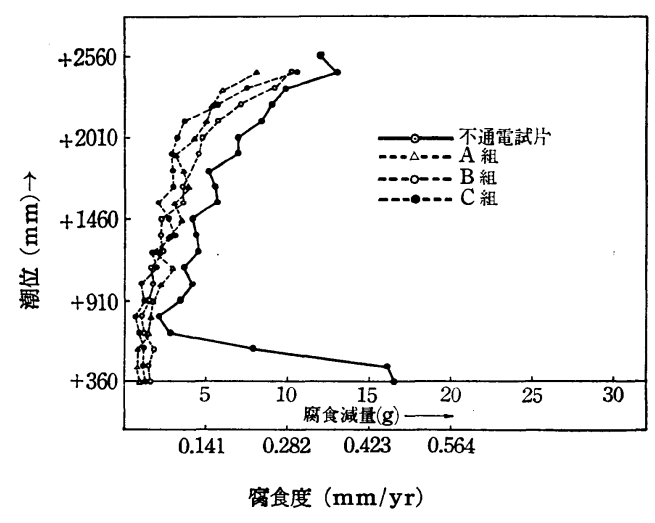

図 9 各潮位での各組腐食減量

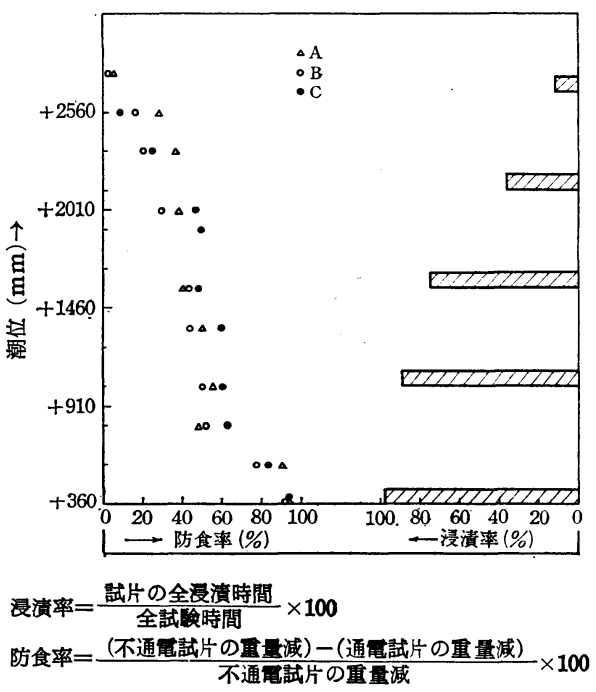

図 10 各組試片の浸漬率と防食率の関保

ている。防食効果は浸漬率の低下とともにいずれの組も 低下するが, 特に浸漬率 $40 \%$ 以下では急激な低下を示 す。この点を各組について比較してみると，低下の度合 は $\mathrm{A}$ 組が最も大きく， C 組が最も小さくなっている。

\section{4. 考察}

浸漬率と通電量についてみると，防食率が 50 ～60\% を示す部分では次のようになる。浸漬率 $95 \%$ の場合 1 回の浸漬時間は $12 \mathrm{hr} \times 0.95=11.4 \mathrm{hr}$ であり，この值 と図 8 とから 2 力月目（初期）と 7 力月目 (後期) の通 電量は各々 A, B 両組では $25.5 \sim 38.2 \mathrm{~A} \cdot \mathrm{hr} / \mathrm{m}^{2}$ (初期) と $1.7 \sim 2.28 \mathrm{~A} \cdot \mathrm{hr} / \mathrm{m}^{2}$ (後期)，C 組では $51 \mathrm{~A} \cdot \mathrm{hr} / \mathrm{m}^{2}$ （初期）と $25.5 \mathrm{~A} \cdot \mathrm{hr} / \mathrm{m}^{2}$ (後期) になる。また $40 \%$ 浸 漬率では 1 回の浸漬時間は $12 \mathrm{hr} \times 0.4=4.8 \mathrm{hr}$ であり， $\mathrm{A}, \mathrm{B}$ 両組では $14 \sim 16 \mathrm{~A} \cdot \mathrm{hr} / \mathrm{m}^{2}$ (初期) と $0.72 \sim 0.96$ $\mathrm{A} \cdot \mathrm{hr} / \mathrm{m}^{2}$ (後期), C 組では $21.5 \mathrm{~A} \cdot \mathrm{hr}$ (初期) と $14 \mathrm{~A}$. $\mathrm{hr} / \mathrm{m}^{2}$ (後期) になる。通常エレクトロコーティングを施 寸場合は $60 \sim 100 \mathrm{~A} \cdot \mathrm{hr} / \mathrm{m}^{2}$ 程度を採用しているが，本 
試験の場合では初期でも最大 $50 \mathrm{~A} \cdot \mathrm{hr} / \mathrm{m}^{2}$ 程度であり, 通電量が少ない。さらに 1 回の浸漬時間が 10 時間以下 に制限されるので，いずれから見ても良質の皮膜生成の 条件には欠けている。特に浸漬率 $40 \%$ 以下では 1 回の 浸漬時間が 5 時間以下となるので, 通電量以外に大気中 にある時間での腐食が支配的となるばかりでなく，石灰 質皮膜の付着が過度のものでは，その密着性がよい場合 には干潮時の防食性を発揮するが，逆海水を含んだ湿 潤状態を維持する傾向となるため, 防食効果低下をきた したものと考元られる。この点は Humble む指摘して いるが, 皮膜の性状, 引上げ直前に測定した電位減衰状 態からもうかがえる。A， B, C 各組のうちでは防食電位 に近い $\mathrm{A}$ 組が浸漬率にあまり影響なく平均した防食効 果をあげている点は興味がある。これはこの種の乾, 湿 を繰り返す部分に対しては高電流密度を一時に与えるよ りも, むしろ低電流密度を繰り返し与える方がよいこと を示しているものと思われる。また工場地帯の近くの海 水は本試験に使用した海水と異なり相当の油分を含えで いる場合が多い。油分は鋼材表面特に干満潮面に多く付 着して, 干潮時大気中にある面の腐食を防止する効果を 発揮する。従ってこの作用を考虑すれば本試駼程度の電 位変化を対象面に与えれば，防食効果は 50〜60\% をさ らに上回ることが考劣られる。事実このような環境での 試験では $70 \%$ 以上の防食率を示しており, Ambler \& Bain ${ }^{2)}$ も油分の影響を相当大きく見ている。本試験の結 果は油分の影響のない場合であるが, 上述のごとく電気 防食適用分野からみて, この種の環境は条件のわるい所
といえる。

\section{5. 総括}

干満部において浸漬時の電位を海水塩化銀電極基準で $-900 \mathrm{mV} \sim-1,000 \mathrm{mV}, \quad-1,000 \mathrm{mV} \sim-1,100 \mathrm{mV}$, $-1,200 \mathrm{mV}$ 近辺に保った場合の黑皮付軟鋼板の防食効 果を調查した結果

1）浸漬率が $95 \%$ 付近では常時浸漬部と同程度に 95〜98\% の防食効果をあげうる。

2）浸漬率が 40〜 90\% の範囲では $-1,200 \mathrm{mV}$ 近 辺のものが防食効果はやや高いが， 3 組とも大差なく 50〜60\% の防食効果を示した。

3）浸漬率 $40 \%$ 以下ではいずれの場合む防食効果法 急激に低下するが, その内では $\mathrm{A}$ 組 $(-900 \mathrm{mV} \sim-1,000$ $\mathrm{mV}$ ) のものが低下の度合が少なく表面状態も良好であ った。

4) 従ってこの種の環境では防食電位近くに対象面の 電位を保特するのが勃果的，かつ経済的である。

5）特に浸漬率 $40 \%$ 以下の部分には電気防食とこれ 以外の防食法を併用することが望ましい。

終りに本試験場所を貸与下された出光興産株式会社並 びに同社関係各位, 本発表をご許可下された弊社花田常 務, 有益なるご指導をたまわった金属材料技術研究所小 林豊治室長, および本測定にご協力願った各位に厚くお 礼申上げます。 (昭和 40 年 3 月 8 日受理)

\section{参考 文 献}

1) H. A. Humble: Corrosion, 5, 292 (1949)

2) H. R. Ambler \& A. A. J. Bain: J. Appl. Chem., 5, 437 (1955) 